\section{Positions Available}

\section{PHYSICAL METALLURGIST}

Tenure-track position for assistant or associate professor in a university-designated eminent program in materials with opportunity to associa te with established multidisciplinary materials research groups on campus. Forty hours work per week for the nine-month academic year. Duties include teaching undergraduate and graduate courses in physical metallurgy, including structural characterization of materials by $x$-rays and by optical and electron microscopy; conducting and guiding research; and participation in department affairs. An earned doctorate in metallurgy/materials or related field is required: post-doctoral experience highly desirable. Salary range: $\$ 26,000-\$ 46,000$ depending upon qualifications and experience. Position available 1 January 1987: Applications accepted until it is filled. Contact H.W. Weart, Chairman, Dept. of Met. Engr., Univ, of Missouri-Rolla, Rolla, MO 65401. UMR is an equal opportunity institution.

\section{CHAIRPERSON DEPARTMENT OF CHEMICAL ENGINEERING Clarkson University}

Clarkson University invites nominations/ applications for the position of Chairperson, Department of Chemical Engineering. The department has 20 faculty members and 80 graduate students with nine PhD degrees granted this year. The department emphasizes excellence in research and teaching with more than a million dollars of external research funding. A university-wide Center for Advanced Materials Processing (CAMP) has been established and is expected to have associated with it a NASA Center for the Development of Commercial Crystal Growth in space and a New York State Center for Advanced Technology in Materials Processing to be housed in a new research building dedicated to materials processing. The department will play a major role in these activities with its former chairman, Dr. William R. Wilcox, as Director of CAMP.

Candidates for the Chairperson position should possess the $\mathrm{PhD}$ degree in Chemical Engineering and have demonstrated capabilities in leadership, administration, and an international reputation in research in chemical engineering. Nominations/ applications should be sent to S.V. Babu, Search Committee Chairperson, Department of Chemical Engineering. Clarkson University, Potsdam, NY 13676. Closing date for applications is October $31,1986$.

Clarkson University is an

Equal Opporfunity/Altirmative Action Employer (MFHV)
FACULTY POSITION MATERIALS SCIENCE AND ENGINEERING

\section{University of Wisconsin-Madison}

We are looking for candidates who are interested in a teaching/research career in though we are open to any outstanding individuals, special attention will be given to those with expertise in electron $\mathrm{mi}$ croscopy as applied to non-metallic materials. Academic rank is open depending on candidate's qualifications. The Department of Metallurgical and Mineral Engineering and the College of Engineering have research activities in the areas of metals, semiconductors, and polymers. We have recently added several faculty in the ceramic area and are looking for additional faculty in the materials field The person must have the capability of developing an active research program and interact effectively with others. Interested persons should submit an application including a resume and a list of three references to: Professor $Y$. Austin Chang. Department of Metallurgical and Mineral Engineering, University of Wisconsin-Madison, 1509 University Avenue. Madison, Wisconsin 53706.

Equal Opportunity Employer Materials Science and Engineering. Al-

\section{ON-SITE SHORT COURSES}

\section{conducted at your facilities or a nearby site}

Vivienne Harwood Mattox MRS Short Course Manager

Materials Research Society

440 Live Oak Loop

Albuquerque, NM 87122

1505) 294-9532

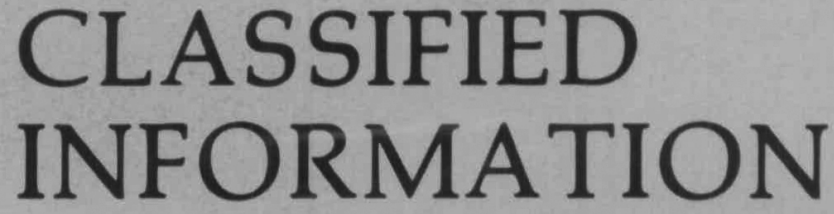

- Positions available

- Positions wanted

- Professional services

\section{Call today to place your ad in the next issue.}

\author{
Contact: Mary Kaufold, MRS BULLETIN, Materials Research Society, \\ 9800 McKnight Road, Suite 327, Pittsburgh, PA 15237; \\ telephone (412) 367-3012
}

